\title{
Original
}

\section{Analysis of dental health education activity carried out by dentistry students}

\author{
María E. López de Bocanera, María E. Colloca, Judit N. Schallmach \\ and A. Chervonagura de Gepner
}

Cátedra de Química Biológica, Facultad de Odontología, Universidad Nacional de Tucumán (U.N.T.), Argentina

(Received 17 September 1996 and accepted 16 April 1997)

\begin{abstract}
During their career, students of dentistry acquire techniques which they will employ later on their patients. Since the health of these patients and society itself cannot be left exclusively to the professional activity of these future dentist, an experimental extra-class experience was carried out with pupils from primary and secondary schools. The students gave the pupils presentations on Nutrition, Calcium and Phosphorus and Caries. The aim of this study was to evaluate: a) the influence of society on the teaching process, and training during the first university year, and b) epidemiologic aspects. Our results indicated that $32.2 \%$ of the primary and 15.6 $\%$ of the secondary school pupils were unfamiliar with the disciplines presented by the students. According to the evaluations $78.1 \%$ of the primary and $94.0 \%$ of the secondary school pupils achieved or exceeded the minimum requirements considered necessary for correct nutritional and oral health habits. Evaluations of the students demonstrated that the students who had participated in the activity did not have knowledge superior to that of non-participating students. Therefore this experience can be considered an exercise in utilizing human resources for primary prevention rather than an innovative methodology which improves the teaching-learning process. It also seems recommendable in view of the low cost of the exercise.
\end{abstract}

Key words: teaching activity; oral public health education; dentistry students.

\section{Introduction}

The Advisory Committee on Medical Research of the World Health Organization (WHO) considers that research on health services should involve the systematic study of ways through which biomedical and any other related knowledge influence the promotion of health of individuals and society (1). These services involve close collaboration with public education, so that individuals can acquire new merits, increase comprehension about themselves and the society in which they live (2), and

Correspondence to Dr. María Elena López de Bocanera, Av. Benjamín Aráoz 800, (4000) S.M. de Tucumán, Argentina. accept changes in their lifestyle. Therefore it is essential that prevention plans are applied to children and adolescents in order that they can achieve high levels of psycho-physical health, according to their socialeconomic resources and the characteristics of the region where they live.

School as an educative institution and the teacher as educational symbol are elements of disease prevention plans from which health knowledge can be transferred to the home. In the particular case of dental education and disease prevention, a teacher can teach in a natural way (3), whereas a dentist can be a stranger often regarded with distrust and sometimes associated with fear. The aim of our dental students was different. They proposed to develop a public education program which attepted to provide a service to the community on the one hand, and to utilize the classroom at the pre-graduation education level on the other (4). In this way, universities as a source of knowledge could become socially accessible and play a role in public health promotion by directly applying the results of their research.

Based on these aims, an extra-class program for firstyear students of dentistry was developed. The objective was to put into practice an active methodology which would be efficient and effective for the target population $(5,6)$, and to allow the students to divulge oral prevention. The aim of this epidemiological survey was to analyse this activity and to evaluate the results obtained from both the target population and the participating students $(7,8)$.

\section{Materials and Methods \\ Participating population}

The survey included pupils, students and their respective teachers making a total of 483 participants.
A) Pupils. This group included:
a) 118 primary school pupils between their 4 th and 7 th years, aged between 9 and 12 .
b) 218 secondary school pupils between their 1 st and 3rd years, aged between 13 and 15 .

B) Students. This group included 126 students studying Dental Biochemistry, forming part of Biological Chemistry, a first-year course of the Career Dentistry Program of the Universidad Nacional de Tucumán. 
C) Primary and Secondary School Teachers. This group included a total of 13 teachers; 6 teaching in primary and 7 in secondary schools. All attended the activities carried out by the students. Teachers had an average service of $16.5 \pm 11.6$ years.

D) University Teachers. This group consisted of 8 lec-turers who coordinated and assisted the activities carried out by the students. Average length of service was $10.9 \pm 13.5$ years.

\section{Students' activities}

Students were divided into groups of 4-5 people, and were assigned to one of the following three Dental Biochemistry subjects: a) Nutrition, b) Calcium and Phosphorus and c) Caries (N-S, CaP-S and C-S respectively).

Each group of students gave only one presentation. Primary school pupils, however, received weekly presentations from each students' group on each of the three subjects for three consecutive weeks. Secondary school pupils received only presentations on Nutrition and Caries, because the concepts of Calcium and Phosphorus were included in these two subjects. The students were assigned the year and level (primary or secondary) of the pupils. They had to give a presentation during the first $20 \mathrm{~min}$, and then to perform planned activities with the pupils. Illustrations and pictures were used in all presentations, and in some of them other utilities were employed, such as slides, overhead sheets and didactic models of dental material. Colorimetric methods were used to show the nutritional value of certain food products. Afterwards the pupils worked in groups on crosswords, puzzles and other letter games related to the subjects.

\section{Questionnaires}

Pupils, students and their respective teachers had to respond to questionnaires on the last day of the experience. These were based on closed (yes-no) answers (5), and contained numeric or descriptive scales (4). Three groups of questions on the following subjects were included:

1) Personal data of the participants.

2) Analysis of the pupils' conditions at the time of doing the exercise.

a) Nutritional state

b) Degree of dental care and hygiene

3) Analysis of the teaching activity of the students.

a) Relationship among the students themselves, among the students and their pupils and among the students and their teachers

b) Discussion subjects

c) Methodology

Table 1 Distribution of 336 primary (4th to 7th year) and secondary (1st to 3rd year) pupils and 126 dentistry students according to sex and age.

\begin{tabular}{|c|c|c|c|c|}
\hline Year & $\begin{array}{l}\text { Number } \\
\text { of Pupils }\end{array}$ & & 6) ${ }^{*} \mathrm{~F}$ & Age $(x \pm S D)$ \\
\hline 4 & 27 & 56.3 & 43.7 & $10.4 \pm 1.5$ \\
\hline 5 & 41 & 40.7 & 59.3 & $10.5 \pm 1.2$ \\
\hline 6 & 23 & 45.0 & 55.0 & $11.8 \pm 1.0$ \\
\hline 7 & 27 & 42.3 & 57.7 & $12.9 \pm 1.0$ \\
\hline 1 & 84 & 43.2 & 56.8 & $13.6 \pm 0.85$ \\
\hline 2 & 75 & 41.4 & 58.6 & $14.0 \pm 1.0$ \\
\hline 3 & 59 & 42.4 & 57.6 & $15.0 \pm 1.3$ \\
\hline $\mathrm{N}-\mathrm{S}^{* *}$ & .52 & 26.9 & 73.1 & $18.7 \pm 1.5$ \\
\hline $\mathrm{CaP} \mathrm{S}^{* *}$ & 23 & 34.8 & 65.2 & $19.4 \pm 1.7$ \\
\hline $\mathrm{C}-\mathrm{S}^{* *}$ & 51 & 35.3 & 64.7 & $19.3 \pm 1.5$ \\
\hline
\end{tabular}




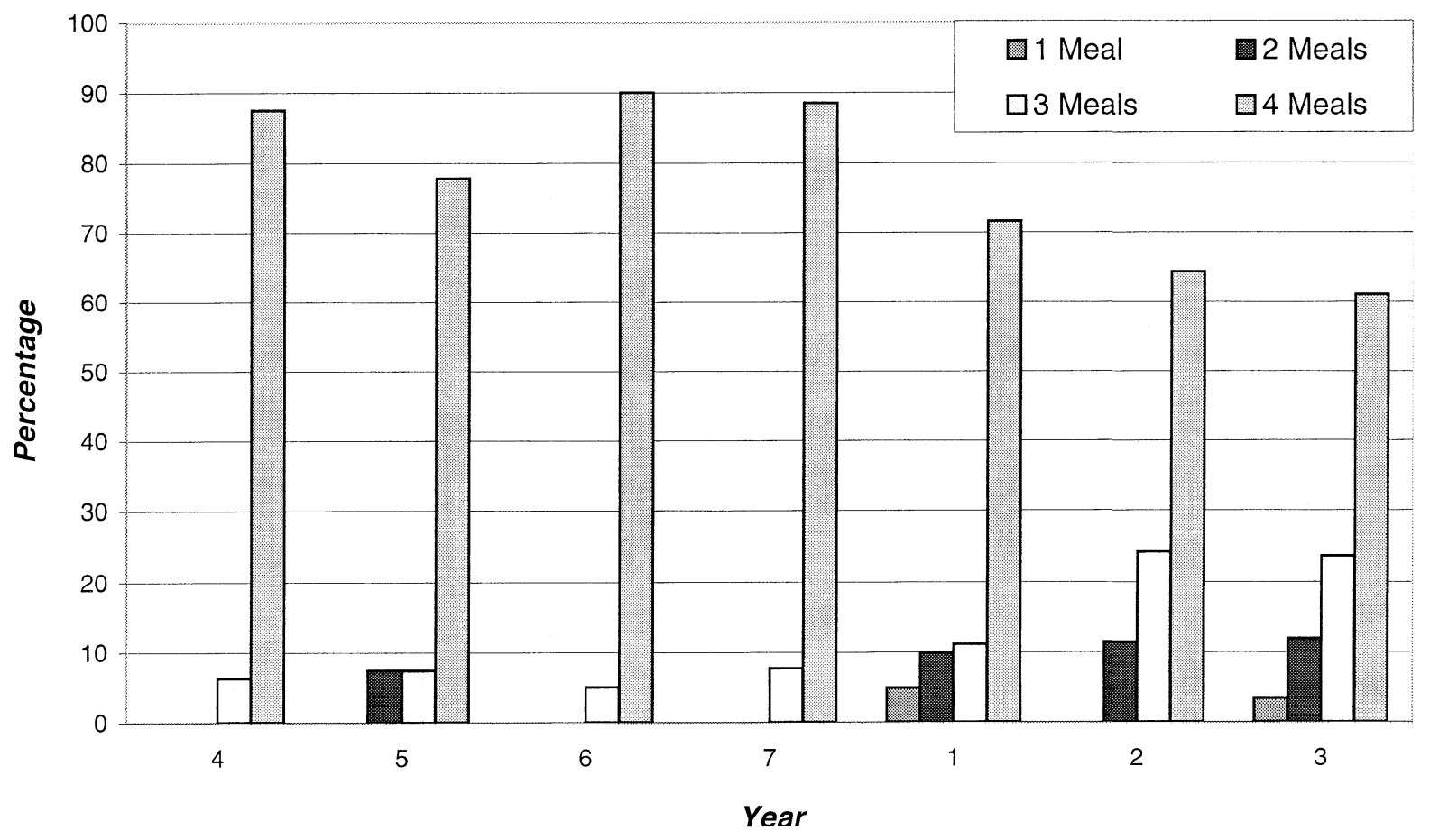

Fig. 1 Distribution (\%) of 336 primary (4th to 7 th year) and secondary (1st to 3rd year) pupils according to the number of daily meals (breakfast, lunch, tea and supper).

\section{Evaluation of the target population}

Eleven days after the last presentation the pupils were given a written evaluation of a formative kind (4). Highly difficult questions were not included, because the aim was to know the acquired knowledge on each of the given subjects.

Both primary and secondary school pupils were given the same evaluation, as only elemental aspects were questioned, that would guarantee the preventive nature of this activity. The pupils received a questionnaire with structured identification questions (4) and they had to choose the answer they thought most appropriate.

The minimum requirement was that $60 \%$ or more of the questions had to be answered correctly. Unanswered questions were also registered.

The difficulty rate (d) was defined as the percentage of correct answers given by all pupils divided by the total number of questions given to all pupils: $d=c / n \times 100$, being " $c$ " the number of correctly answered questions and " $n$ " the total number of questions. A value for $\mathrm{d}$ between $0 \%-15 \%$ was defined as very difficult, $16 \%-31 \%$ relatively difficult, $32 \%-68 \%$ slightly difficult, $69 \%-84$ $\%$ relatively easy and $85 \%-100 \%$ very easy (4).

\section{Evaluation of the students}

Nineteen days after the last presentation, the students were evaluated. The test contained an evaluation of the level of knowledge on the three studied subjects and three other subjects not incorporated in the experience. The evaluation consisted of short answer questions (4), and the minimum pass requirement was defined as $60 \%$ or more of the questions answered correctly.

The same evaluation criterion was applied to 38 other students who had not participated in the experience (OS). The following were analysed:

a) answers of all students (with and without participation in the exercise) to the subjects presented to the pupils.

b) answers of all students (with and without participation in the exercise) to other subjects.

The difficulty rate (d) was defined in a similar way to that used for the pupils.

Statistics. Where necessary, data were analysed by the chi-squared (c2) test (9).

\section{Results}

Personal data of the participating groups

Table 1 shows the distribution of primary and secondary school pupils and students participating in the experience. Female participants were dominant in all three groups. Similarly, $84.6 \%(n=11)$ of the primary and secondary school teachers, and $100 \%$ of the university teachers were female.

The average age of primary school pupils was $11.4 \pm$ 1.2 years, that of secondary pupils $14.2 \pm 0.7$ years, and that of students $19.1 \pm 0.4$ years.

\section{Nutritional state of the pupils}

Pupils were asked about the number of daily meals (breakfast, lunch, tea and supper) they took. The results are shown in Figure 1 (unanswered questions are excluded). Primary school pupils had a larger number of daily meals than secondary school pupils.

When questioned about the quality of their daily food intake, both groups stated they had a diet consisting of carbohydrates, proteins and lipids (Table 2) ; 67.0\% of 
Table 2 Distribution of 336 primary (4th to 7 th year) and secondary (1st to 3rd year) pupils according to their type of nutrition. Values are given as percentages (\%).

\begin{tabular}{|c|c|c|c|c|c|c|}
\hline Year & Milk & Meat ${ }^{*}$ & Eggs & Vegetables & Fruits & Others ${ }^{* *}$ \\
\hline 4 & 93.7 & 100.0 & 81.3 & 75.0 & 81.3 & 93.7 \\
\hline 5 & 74.1 & 74.1 & 55.6 & 70.4 & 81.5 & 92.6 \\
\hline 6 & 40.0 & 65.0 & 35.0 & 70.0 & 55.0 & 65.0 \\
\hline 7 & 76.9 & 88.5 & 61.5 & 69.2 & 76.9 & 80.8 \\
\hline 1 & 67.9 & 90.1 & 66.7 & 86.4 & 93.8 & 87.7 \\
\hline 2 & 47.1 & 88.6 & 72.9 & 74.3 & 44.3 & 91.4 \\
\hline 3 & 69.5 & 89.8 & 69.5 & 81.4 & 88.1 & 94.9 \\
\hline TOTAL & $\begin{array}{c}67.0 \pm \\
18.2\end{array}$ & $\begin{array}{c}85.2 \pm \\
11.7\end{array}$ & $\begin{array}{c}63.2 \pm \\
14.9\end{array}$ & $\begin{array}{c}75.2 \pm \\
6.5\end{array}$ & $\begin{array}{c}74.4 \pm \\
18.0\end{array}$ & $\begin{array}{c}86.6 \pm \\
10.6\end{array}$ \\
\hline
\end{tabular}

\section{*) Different kinds of meat}

** ) Others: Pasta products, maize flour and rice

the pupils $(\mathrm{n}=225)$ consumed milk, whereas the rest only drank tea or mate (green tea). Although these data reveal a good nutritional health state, $76.9 \%$ of the teachers $(n=$ 10) rated it as fairly good, based on their daily observation; $0.08 \%(\mathrm{n}=1)$ of them said they were unable to respond due to insufficient information.

\section{Oral care and hygiene of the pupils}

The pupils were questioned about their frequency of intake of sweets, daily tooth brushing and visits to the dentist (Table 3; unanswered questions are not included).

The results from both the primary and secondary school pupils indicated only a small intake of sweets, and the majority of the pupils said that they brushed their teeth regularly. However, nearly all of them said they visited a dentist only when they felt pain, and did not pay regular visits (Fig. 2). Although secondary school pupils eat more sweets daily, they appear more concerned about oral hygiene. Nevertheless, similar to the primary school pupils, they do not pay regular visits to the dentist.

According to daily observation, $61.5 \%(n=8)$ of primary and secondary school teachers stated that toothbrushing by their pupils was not very frequent. The rest $(38.5 \%, \mathrm{n}=5)$ said that they were not able to respond to this question due to lack of information. The same answer was obtained with $69.2 \%(n=9)$ of these teachers, when they were asked about visits to the dentist by the pupils.

\section{Interpersonal relationships}

Communication among the students themselves and between them and teachers during the preparation of presentations was rated as very good by both groups: 69.8 $\%(\mathrm{n}=88)$ of the students said they had participated and collaborated with other students.

With regard to the interpersonal relationships with pupils, both primary and secondary school teachers (84.6 $\%, \mathrm{n}=11)$ and university teachers $(100 \%)$ agreed that they were very satisfactory. Their opinion was based on the fact that the pupils received the presentations respectfully and with good behaviour; $70.6 \%(n=89)$ of the students agreed.

\section{Discussion subjects}

$32.2 \%(n=38)$ of the primary and $15.6 \%(n=34)$ of the secondary school pupils stated that they did not have any knowledge about the subjects prior to the students' presentations. This opinion agreed with that of the teachers. Only 4th and 5th year teachers said they had taught subjects similar to those in the trial. 
Table 3 Distribution of 336 primary (4th to 7th year) and secondary (1st to 3rd year) pupils according to their habits related to dental health. Values are given as percentages (\%).

\begin{tabular}{|c|c|c|c|c|c|c|c|c|c|c|c|c|c|}
\hline \multirow[b]{2}{*}{ Year } & \multicolumn{3}{|c|}{ Intake of sweets } & \multicolumn{3}{|c|}{$\begin{array}{c}\text { Daily tooth } \\
\text { brushing }\end{array}$} & \multicolumn{4}{|c|}{$\begin{array}{l}\text { Number of daily } \\
\text { tooth brushing }\end{array}$} & \multicolumn{3}{|c|}{ Visits to the dentist } \\
\hline & $\begin{array}{l}\text { Some } \\
\text { times }\end{array}$ & Often & Never & Yes & No & $\begin{array}{l}\text { Some } \\
\text { times }\end{array}$ & $\begin{array}{c}1 \\
\text { Time }\end{array}$ & $\begin{array}{c}2 \\
\text { Times }\end{array}$ & $\begin{array}{c}3 \\
\text { Times }\end{array}$ & $\begin{array}{c}4 \\
\text { Times }\end{array}$ & Regularly & $\begin{array}{c}\text { Not } \\
\text { Regularly }\end{array}$ & Never \\
\hline 4 & 87.5 & 6.3 & 0.0 & 81.3 & 0.0 & 12.5 & 12.5 & 18.8 & 43.8 & 6.3 & 12.5 & 68.8 & 18.8 \\
\hline 5 & 33.3 & 55.6 & 11.1 & 63.0 & 7.4 & 3.7 & 7.4 & 14.8 & 25.9 & 40.7 & 18.5 & 66.7 & 18.5 \\
\hline 6 & 25.0 & 70.0 & 0.0 & 30.0 & 25.0 & 35.0 & 35.0 & 25.0 & 30.0 & 0.0 & 10.0 & 55.0 & 35.0 \\
\hline 7 & 50.0 & 30.8 & 11.5 & 80.8 & 0.0 & 11.5 & 0.0 & 23.1 & 23.1 & 50.0 & 3.8 & 73.1 & 15.4 \\
\hline 1 & 67.9 & 24.7 & 7.4 & 64.2 & 1.2 & 33.3 & 16.0 & 27.2 & 32.1 & 21.0 & 12.3 & 69.1 & 18.5 \\
\hline 2 & 80.0 & 20.0 & 0.0 & 82.9 & 0.0 & 15.7 & 15.7 & 38.6 & 30.0 & 15.7 & 1.4 & 80.0 & 18.6 \\
\hline 3 & 72.9 & 22.0 & 5.1 & 84.7 & 1.7 & 13.6 & 11.9 & 42.4 & 32.2 & 10.2 & 5.1 & 66.1 & 28.8 \\
\hline
\end{tabular}

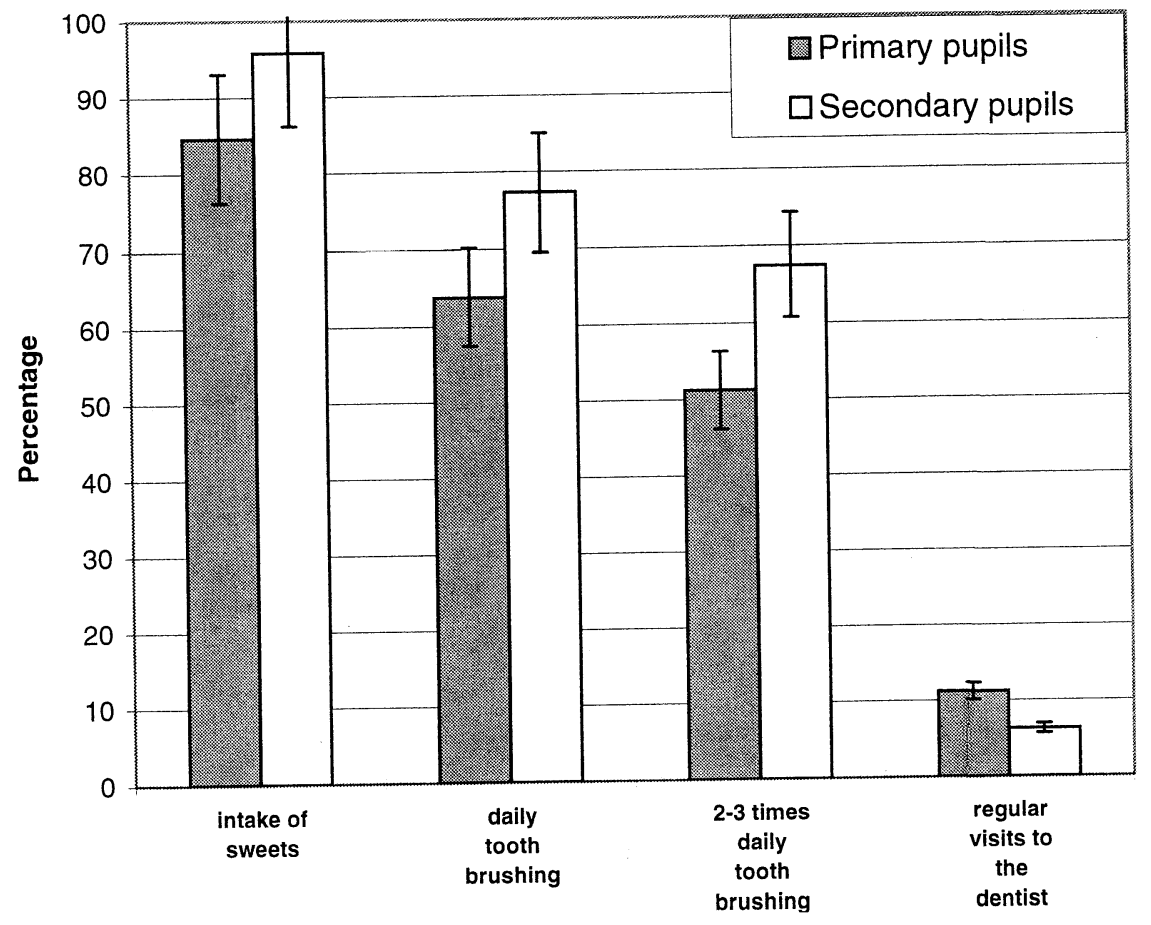

Fig. 2 Distribution (\%) of 336 primary and secondary pupils according to their habits of dental health. 
Table 4 Distribution of 126 dentistry students according to their responses to questions on Nutrition, Calcium and Phosphorus, Caries and 38 other subjects. Percentages are given for the numbers of students who passed or equalled the minimum requirements and for the numbers of unanswered questions.

\begin{tabular}{|c|c|c|c|c|c|c|c|c|}
\hline & \multicolumn{2}{|c|}{ Nutrition } & \multicolumn{2}{|c|}{$\begin{array}{l}\text { Calcium and } \\
\text { Phosphorus }\end{array}$} & \multicolumn{2}{|c|}{ Caries } & \multicolumn{2}{|c|}{ Other Subjects } \\
\hline & $\begin{array}{l}\text { Minimum } \\
\text { requirements }\end{array}$ & $\begin{array}{c}\text { Unanswered } \\
\text { questions }\end{array}$ & $\begin{array}{c}\text { Minimum } \\
\text { requirements }\end{array}$ & $\begin{array}{c}\text { Unanswered } \\
\text { questions }\end{array}$ & $\begin{array}{l}\text { Minimum } \\
\text { requirements }\end{array}$ & $\begin{array}{l}\text { Unanswered } \\
\text { questions }\end{array}$ & $\begin{array}{l}\text { Minimum } \\
\text { requirements }\end{array}$ & $\begin{array}{c}\text { Unanswered } \\
\text { questions }\end{array}$ \\
\hline $\mathrm{N}-\mathrm{S} *$ & 66.7 & 21.4 & 77.3 & 14.4 & 69.5 & 18.9 & 65.0 & 13.8 \\
\hline CaP-S* & 66.7 & 22.2 & 60.4 & 15.1 & 69.1 & 10.1 & 60.0 & 9.6 \\
\hline $\mathrm{C}-\mathrm{S} *$ & 48.9 & 42.2 & 59.4 & 15.3 & 58.5 & 28.8 & 59.8 & 22.2 \\
\hline O-S ** & 72.4 & 13.8 & 63.3 & 17.2 & 75.0 & 15.5 & 69.1 & 15.4 \\
\hline Total & $\begin{array}{c}63.7 \pm \\
10.2\end{array}$ & $\begin{array}{c}24.9 \pm \\
12.1\end{array}$ & $\begin{array}{c}65.1 \pm \\
8.3\end{array}$ & $\begin{array}{c}15.5 \pm \\
1.2\end{array}$ & $\begin{array}{c}68.0 \pm \\
6.9\end{array}$ & $\begin{array}{c}18.3 \pm \\
7.9\end{array}$ & $\begin{array}{c}63.5 \pm \\
4.5\end{array}$ & $\begin{array}{c}15.3 \pm \\
5.2\end{array}$ \\
\hline
\end{tabular}

*) N-S, CaP-S, C-S; Students who gave a presentation on Nutrition,

Calcium and Phosphorus and Caries respectively

$\left.{ }^{*}\right)$ O-S, students who had not participated in the experience

\section{$\square$ Minimum contents $\quad$ QUnanswered questions}
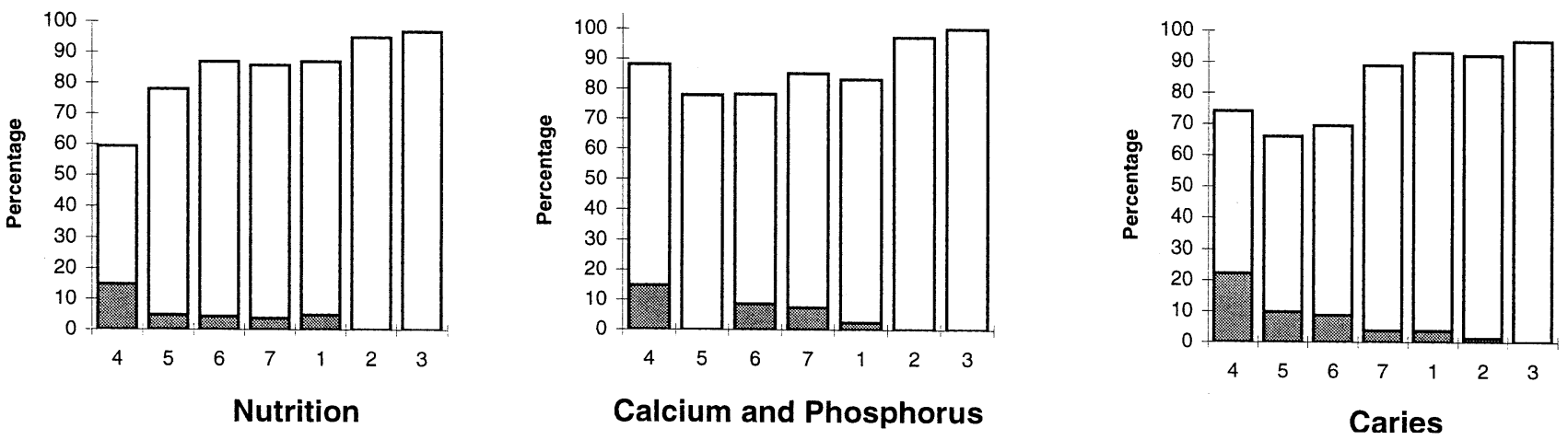

Fig. 3 Distribution (\%) of 336 primary (4th to 7th year) and secondary (1st to 3rd year) pupils according to the response to questions on Nutrition, Calcium and Phosphorus and Caries. 


\section{Evaluation of methodology}

The pupils found the presentations interesting; $86.0 \%$ ( $n=289$ ) of the pupils found themselves motivated to care more about their nutritional and oral health, and 60.7 $\%(n=204)$ said they had transmitted the acquired knowledge to their family. All primary and secondary teachers agreed that the methodology employed was very satisfactory and creative for all pupils. They thought they could transmit the acquired experience to their families and change their nutritional habits and oral hygiene to some degree.

\section{Pupils' evaluation}

Figure 3 shows the results obtained from the pupils' evaluations (results that lacked minimum requirements are not included). In general, a majority of the pupils were able to respond to the questions, although some difficulty was observed with primary school pupils $(\mathrm{d}=$ $78.1 \%)$. The difficulty rate for secondary school pupils was $94.0 \%$. Although these ratios reveal that the evaluation test was relatively easy and very easy, respectively, for the two grades, nearly all pupils assimilated the minimum requirement of the subject content.

\section{Students' evaluation}

The numbers of correctly answered questions on the provided and other subjects were recorded. Table 4 shows that less than $80 \%$ of the students achieved the minimum requirements (results that lacked the minimum requirement are not included). It can also be observed that there was a high percentage of unanswered questions.

Regarding the difficulty rate, values of $66.7 \%, 60.4 \%$ and $58.5 \%$ were found among those students who had participated in the experience when responding to questions about the subjects had presented (percentages for Nutrition, Calcium and Phosphorus and Caries, respectively). This would indicate a moderate degree of difficulty. On the contrary, students who had not participated demonstrated difficulty rates of $72.4 \%, 63.3$ $\%$ and $75.0 \%$ for the same subjects, respectively, indicating that the task was relatively easy for them.

Chi-squared test was applied to analyse the number of correct and incorrect answers given by participating groups (answers of each of the three groups only to the subjects each group had presented) and by a group which had not participated (answers of one group to all three subjects). The results given by both groups were significantly different $(\mathrm{p}<0.01)$. For participating students, no significant difference was observed between answers to questions related to their presentations and other subjects $(\mathrm{p}<0.01)$. These results indicated that the learning process of the students had not been altered, probably because this experience consisted of consulting easily accessible pupil texts, rather than demanding bibliography.

\section{Discussion and Conclusion}

In this study we conducted an extra-class teaching experience and an analysis to evaluate its effectiveness as a means of primary prevention and the influence of society on the learning process of the students.

The exercise was carried out in an urban district of San Miguel de Tucumán, Argentina. The students worked out the discussion subjects of their presentations, which were included in the Dental Biochemistry course, forming part of the Biological Chemistry course. Tooth-brushing techniques or other preventive measures were not applied as they had not yet been included in the students' course. Twenty-four percent of the participating pupils said they had no previous notion of the presented subjects. Only 4 th and 5th year teachers said they taught related subjects. Therefore both the subjects and the methodology employed were of interest to the pupils. Adequate use of language by the students, facilitating the interpersonal relationship, may have been associated with this achievement.

Analysis of habits related to the nutritional and dental health of the pupils showed that they had reasonably satisfactory alimentation and fulfilled certain requirements of dental hygiene. However, a significant percentage of their teachers considered that both aspects were insufficient for the pupils and their families, which could be explained by thedifficulty in expressing their bad habits.

After this experience, both primary and secondary school pupils stated that they could take better care of their nutritional and dental health, and that they had transmitted the acquired knowledge to their families. Though the evaluations are not conclusive, they indicate that through this experience the pupils acquired elementary concepts, which helped them to improve their nutritional and dental habits. A significant percentage of both primary and secondary school pupils demonstrated that they had achieved or exceeded the minimum knowledge requirements. The evaluations of the students demonstrated statistically that the teaching-learning process was not improved by incorporation of society.

The students, who were not much older than their audience, expressed great personal satisfaction after the experience, as they had felt they had played a role in the Health Service and contributed to improving the quality of public life (10).

Most $(98.4 \%)$ of the pupils expressed their interest to acquire more information in the coming years. Although neither a diagnosis nor clinical history of the target population $(11,12)$ was carried out, the exercise contributed to the formation of human resources. Similar exercises could also be employed and analysed in similar surveys in suburban and rural areas, characterised by a low cultural level, to help decrease the risk factors and prevalence of caries in the population (13).

\section{Acknowledgements}

This work was partially supported by Proyecto UNI (Una Nueva Iniciativa), Fundación Kellogg and the Facultad de Odontología, U.N.T. The authors wish to thank Lic. Elena B. de Lavanda for her help in making the questionnaires and Dr. Alberto Nazr for statistical advice. 


\section{References}

1. Kelmendi de Ustaran, J. (1992) Epidemiología. 1st ed., 135-140, EUDEBA, Buenos Aires

2. Montilva, L. (1992) Evaluación y control de calidad. In Centro Iberoamericano para el Desarrollo de la Docencia en Odontología, Escuela de Odontología, ed., Universidad de Puerto Rico, San Juan, 26-74

3. Rossetti, H. (1995) Salud para la Odontología. 1st ed., 65-86, Merklen, D., ed., Buenos Aires, Argentina

4. Programa de Formación Docente Pedagógico. Curso de Aprendizaje y Evaluación. Series No. 2, (1992) Panamerican Health Organization, Washington DC, 4-8

5. Polgar, S. and Thomas, S.A. (1993) Introduction to Research in the Health Sciences. 2nd ed., 163-178, Alhambra Longman, Madrid

6. Programa de Desarrollo de Políticas de Salud. Setting priorities in prevention. (1992) Panamerican Health Organization/World Health Organization, Washington DC

7. Guerrero, R., González, C.L. and Medina, E. (1986) Epidemiología, Iberoamericana, Wilmington, 70-89
8. Polit, D. and Hungler, B.P. (1987) Nursing Research: Principles and Methods. 4th ed., McGraw-Hill, Mexico, 49-69

9. Weintraub, J.A., Douglass, Ch.W. and Gillings, D.B. (1989) Biostats, Data Analysis for Dental Health Care Professionals. 1st ed., Panamerican Health Organization, Chapel Hill, 141-148

10. Norlin, P., Steen, B., Birkhed, D. and Björn, A.L. (1993) On the relations between dietary habits, nutrients and oral health in women at the age of retirement. Acta Odontol. Scand., S1, 277-283

11. Chestnutt, I.G., Jones, P.R., Jacobson, A.P., Shäfer, F. and Stephen, K.W. (1995) Prevalence of clinically apparent recurrent caries in Scottish adolescents, and the influence of oral hygiene practices. Caries Res., 29, 266-271

12. González Cabezas, C. and Fontana Marsh, M. (1992) Estudio epidemiológico de nutrición y caries en una población preescolar de un barrio marginal de Caracas. Acta Odont. Venez., 30, 29-33

13. Grindefford, M., Dahllöf, G., Nilsson, B. and Modéer, T. (1995) Prediction of dental caries development in 1-year-old children. Caries Res., 29, 343-348 